\title{
EFFECTS OF SULPHADIMIDINE ON THE TOXICITY OF PHENOBARBITAL, PENTETRAZOLE AND BEMEGRIDE IN MICE OF DIFFERENT AGES
}

\author{
J. ŠIMƯNEK, EVA HEGEROVÁ, J. JAROŠ and E. TKADLEC
}

Department of Pharmacology and Toxicology, University of Veterinary Science, 61242 Brno

Received fuly 31, 1984

\begin{abstract}
Šimůnek J., Eva Hegerová, J. Jaroš and E. Tkadlec: Effects of Sulphadimidine on the Toxicity of Phenobarbital, Pentetrazole and Bemegride in Mice of Different Ages. Acta vet. Brno, 54, 1985: 177-182.

Acute toxicity of phenobarbital sodium salt and of injection solutions of bemegride and pentetrazole administered subcutaneously alone and after premedication with sulphadimidine sodium salt at $0.2 \mathrm{~g} / \mathrm{kg}$ body mass was determined in conventionally read white mice of $12-16$ and $22-27 \mathrm{~g}$ respectively, in body mass. The toxicity of phenobarbital alone was higher for the younger mice, whereas that of the two analeptics of the central nervous system (CNS) was lower for the younger than for the older animals. Premedication with sulphadimidine increased the toxicity of all the drugs under study, having a particularly marked effect in the younger mice.
\end{abstract}

Acute toxicity, phenobarbital, bemegride, pentetrazole, sulphadimidine premedication, mice, age-dependence.

A previous study from our laboratory (Šimůnek et al. 1985) was concerned with the effects of sulphadimidine premedication on the acute toxicity of phenobarbital in cockerels of different ages. The impetus to the study was possible simultaneous action of the two pharmaceuticals in flocks where Sedophen ${ }^{\mathrm{R}}$, a drug containing phenobarbital, is used to tranquilize chickens and sulphadimidine is used therapeutically, e. g. to combat coccidiosis. Considering the differences in the response to drugs between birds and mammals, the present study was designed to investigate this possible interaction with regard to acute toxicity in white mice This time the experiments were extended to cover possible effects of sulphadimidine premedication on the acute toxicity of two central analeptics, pentetrazole and bemegride.

No published data were available to us for direct comparison, particularly as regards the ontogenetic point of view. Nevertheless, it is well established that phenobarbital, like other barbiturates, plays a major role in changing the effects of concurrently administered drugs by affecting the enzyme systems of the body. Thus a number of clinically important interactions have been described. Kvertina and Fendrich (1978), e. g., mentioned the potentiation of the action of the CNS inhibitors; reduced effects of anticoagulants, corticosteroids (glucocorticoids) and riphampicine as a result of enzyme induction; reduced effects of griseofulvine as a result of both enzyme induction and reduced gastrointestinal absorption; and the observation that antacids reduce gastrointestinal absorption of orally administered phenobarbital. Krishna and Bonanomi (1974) described enhanced binding of chloramphenicol to macromolecules of various tissues of phenobarbital-premedicated rats. Dunajev et al., in a long-term experiment with rats given a phenobarbital solution (1 $\mathrm{g}$ per 1 ) instead of drinking water, demonstrated the activation of hepatocyte enzymes.

According to Skovsted et al. (1974) sulphonamides can prolong the action of other drugs presumably by retarding their metabolism in the liver. The competitive mechanism of the interaction of sulphonamides with a number of other drugs has been universally recognized (Květina and Fendrich 1978, a. o.) and is in fact the underlying principle of their antimicrobial action (S imůnek as cited by Bentz 1982, a. o.). Lee and Foley (1944) pointed out as early as 1944 that where sulphonamides act concurrently with other drugs, the possibility of both antagonism and potentiation should be considered. As to barbiturates, Csögör et al. (1971) and Csögör 
and Papp (1969) found in their experiments on rats that sulphathiazol potentiated the depressive effect on the CSN of both thiopental and hexobarbital, apparently by its binding to plasma proteins. In this connexion it is of interest to note that Anton (1968, as cited by Mitchel 1970) drew attention to the possibility of unexpected reactions occurring in the binding of sulphonamides to plasma proteins not only upon interaction with other drugs but also as a result of disease. Acetazolamide, chemically ranking among sulphonamides, prolonged sleeping time in mice injected intraperitoneally with phenobarbital by depressing its blood level and enhancing its brain level (Sato et al. 1983).

With respect to central analeptics, pentetrazole and bemegride, few published data were available to us for comparison. According to Horáková et al. (1963) sulphamethoxypyridazine potentiates excitatory effects of pentetrazole; experiments conducted by the latter authors demonstrated a similar effect of sulphadimethoxin but not of sulphamethoxydiazine. In our previous experiments, sulphadimidine blood levels of white mice of two different ages were not much affected by either

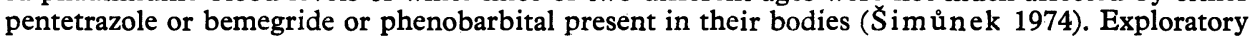
investigations into possible effects on toxicity yielded positive results for the two analeptics, whereas the toxicity of phenobarbital was unaffected. Stone and Javid (1979), in their experiments on mice, studied among other things the antagonism of phenobarbital and pentetrazole and reported its relatively weak manifestations. In the light of their further results they concluded that convulsions observed after administration of pentetrazole or bemegride could not be ascribed primarily to the blocking of GABA-mediated inhibitions. From our previous experiments ( $\mathrm{Sim}$ ưnek 1983 ) it appears that sulphadimidine administered to chickens affects the diazepam-altered $L_{50}$ of pentetrazole by partly cancelling the anti-pentetrazole effect of diazepam.

\section{Materials and Methods}

For experiments with phenobarbital, a total of 576 conventionally-reared white mice were used. Half of them were young animals with an average body mass of $16 \mathrm{~g}$, the other half consisted of adult mice averaging $27 \mathrm{~g}$ in body mass. Each of the two groups was divided into three subgroups. Two of them were premedicated with sulphadimidine 15 or 120 minutes before phenobarbital administration and the remaining subgroup received no premedication. For determination of the $\mathrm{LD}_{50}$, phenobarbital was given in doses of $150,180,210,240,270,300,330$ and $360 \mathrm{mg} / \mathrm{kg}$ body mass using 12 mice ( 6 males and 6 females) with each dose in each subgroup. Aqueous solutions of phenobarbital (phenobarbitalum natricum pulv.) were prepared immediately before subcutaneous injection. Na-sulphadimidine, dissolved in water, was given at $0.2 \mathrm{~g}$ per $\mathrm{kg}$ body mass. Toxicity was expressed in terms of $L_{50}$ values with confidence limits according to Litchfield and Wilcoxon (1949) on the basis of deaths occurring within 48 hours.

For experiments with bemegride, a total of 360 conventionaly-reared white mice of both sexes were used. Half of them were young animals with an average body mass of $12 \mathrm{~g}$, the other half consisted of adult mice averaging $22 \mathrm{~g}$ in body mass. Half of the animals within each of the two groups were alloted for experiments with bemegride and the other half for experiments with pentetrazole. The bemegride- and pentetrazole-treatment groups were each divided further into three subgroups. One of them received no premedication and the remaining two were premedicated with sulphadimidine three hours previously at $0.1 \mathrm{~g}$ or $0.2 \mathrm{~g} / \mathrm{kg}$ body mass, using Na-sulphadimidine in aqueous solution. Pentetrazole and bemegride were given in doses of $100 \mathrm{mg}$ and $45 \mathrm{mg}$ per $\mathrm{kg}$ body mass, respectively, using solutions prepared from commercial products. All drugs were injected subcutaneously and the animals were observed for convulsions and mortality up to 24 hours after administration. The differences of the death rates were evaluated using the law of probability distribution of chi-square values according to a procedure recommended by Myslivec (1957).

All experimental mice were kept in a constant environment. They were fed Larsen's diet ad libitum and had free access to drinking water.

\section{Results}

In all experiments with phenobarbital, deaths occurred within 24 hours of its administration. In the group of young mice no differences in the $\mathrm{LD}_{50}$ values between sulphadimidine-premedicated and non-premedicated animals were recorded for males, whereas in female mice the toxicity of phenobarbital was increased by premedication, the differences between premedicated and non-premedicated animals being 
significant. In adult mice no effects of premedication were observed. In general, the toxicity of phenobarbital proved age-dependent, being higher in young than in adult mice including those of suphlonamide-premedicated subgroups where the relative toxicity for females was even significantly higher.

In experiments with pentetrazole and bemegride the toxicity of the two central analeptics was higher after premedication with sulphadimidine, particularly in the younger mice, irrespective of the sulphadimidine dose level employed. Used without sulphadimidine premedication, the two central analeptics were less toxic for the younger animals. However, the differences between the older and younger animals in the occurrence of convulsions and deaths were not significant.

The results of the experiments are summarized in Tables 1 nad 2.

Table 1

LD $D_{00}$ values (in mg per $\mathrm{kg}$ body mass) of phenobarbital administered subcutaneously alone and after Na-sulphadimidine premedication $(0.2 \mathrm{~g}$ per $\mathrm{kg}$ body mass $\mathrm{s}$. c.), together with percentages of relative toxicity, in white mice of different ages

\begin{tabular}{|c|c|c|c|c|c|c|}
\hline \multirow{2}{*}{ Premedication } & \multicolumn{3}{|c|}{ Mice of $27 \mathrm{~g}$ in body mass } & \multicolumn{3}{|c|}{ Mice of $16 \mathrm{~g}$ in body mass } \\
\hline & o & 우 & $0 \times 0$ & $\pi \times 0$ & 우 & o \\
\hline None & $250 \pm 25$ & $256 \pm 12$ & $255 \pm 12$ & $\begin{array}{l}223 \pm 17 \\
115 \pm 7 \%\end{array}$ & $\begin{array}{l}230 \pm 17 \\
114 \pm 8 \%\end{array}$ & $\begin{array}{l}217 \pm 23 \\
116 \pm 16 \%\end{array}$ \\
\hline $\begin{array}{l}15 \text { min } \\
\text { previously }\end{array}$ & $235 \pm 21$ & $250 \pm 14$ & $249 \pm 18$ & $\begin{array}{l}211 \pm 19 \\
120 \pm 12 \%\end{array}$ & $\begin{array}{l}\star \\
202 \pm 20 \\
125 \pm 13 \%\end{array}$ & $\begin{array}{l}213 \pm 17 \\
110 \pm 13 \%\end{array}$ \\
\hline $\begin{array}{l}120 \min \\
\text { previously }\end{array}$ & $241 \pm 23$ & $248+26$ & $248+16$ & $\begin{array}{l}\star \\
211 \pm 7 \\
118 \pm 10 \%\end{array}$ & $\begin{array}{l}\star \\
208 \pm 19 \\
121 \pm 16 \%\end{array}$ & $\begin{array}{l}212 \pm 26 \\
114 \pm 15 \%\end{array}$ \\
\hline
\end{tabular}

* - Values significantly different $(P<0.05)$ from those obtained in non-premedicated animals.

Table 2 .

Occurrence of convulsions and deaths among white mice injected subcutaneously with pentetrazole or bemegride alone and after premedication with Na-sulphadimidine

\begin{tabular}{|c|c|c|c|c|c|c|c|c|}
\hline \multirow[b]{2}{*}{ Group } & \multicolumn{4}{|c|}{ Mice averaging $22 \mathrm{~g}$ in body mass } & \multicolumn{4}{|c|}{ Mice averaging $12 \mathrm{~g}$ in body mass } \\
\hline & $\begin{array}{c}\text { No. } \\
\text { animals }\end{array}$ & $\begin{array}{c}\text { No. } \\
\text { with } \\
\text { convul- } \\
\text { sions }\end{array}$ & $\begin{array}{l}\text { No. } \\
\text { died }\end{array}$ & $\begin{array}{l}\text { No. } \\
\text { sur- } \\
\text { vived }\end{array}$ & $\begin{array}{c}\text { No. } \\
\text { animals }\end{array}$ & $\begin{array}{l}\text { No. } \\
\text { with } \\
\text { convul- } \\
\text { sions }\end{array}$ & $\begin{array}{l}\text { No. } \\
\text { died }\end{array}$ & $\begin{array}{l}\text { No. } \\
\text { sur- } \\
\text { vived }\end{array}$ \\
\hline $\begin{array}{l}\text { Pentetrazole }(100 \mathrm{mg} / \mathrm{kg}) \\
\text { Without premedication } \\
\text { Na-SD } 0,1 / \mathrm{kg} \\
\text { Na-SD } 0,2 \mathrm{~g} / \mathrm{kg}\end{array}$ & $\begin{array}{l}15 \\
15 \\
15\end{array}$ & $\begin{array}{l}15 \\
14 \\
14\end{array}$ & $\begin{array}{l}11 \\
11 \\
14\end{array}$ & $\begin{array}{l}\mathbf{4} \\
\mathbf{4} \\
1\end{array}$ & $\begin{array}{l}15 \\
15 \\
15\end{array}$ & $\begin{array}{l}14 \\
14 \\
15\end{array}$ & $\begin{array}{r}7 \\
13 \\
11\end{array}$ & $\begin{array}{l}8 \\
2 \\
4\end{array}$ \\
\hline $\begin{array}{l}\text { Bemegride }(45 \mathrm{mg} / \mathrm{kg}) \\
\text { Without premedication } \\
\text { Na-SD } 0,1 \mathrm{~g} / \mathrm{kg} \\
\text { Na-SD } 0,2 / \mathrm{kg}\end{array}$ & $\begin{array}{l}15 \\
15 \\
15\end{array}$ & $\begin{array}{l}14 \\
14 \\
14\end{array}$ & $\begin{array}{l}9 \\
6 \\
9\end{array}$ & $\begin{array}{l}6 \\
9 \\
6\end{array}$ & $\begin{array}{l}15 \\
15 \\
15\end{array}$ & $\begin{array}{l}14 \\
15 \\
14\end{array}$ & $\begin{array}{c}4 \\
10^{\star} \\
10^{\star}\end{array}$ & $\begin{array}{r}11 \\
5 \\
5\end{array}$ \\
\hline
\end{tabular}

* - Values significantly different $(P<0.05)$ from those obtained in non-premedicated animals. 


\section{Discussion}

The results of the experiments reported here demonstrated age-dependent differences in the toxicity of the two drugs acting on the CNS. In our previous experiments with pentetrazole and bemegride alone ( $\zeta$ imủnek et al. 1971a) the acute toxicity of the former was lower for young than for adult mice, whereas the toxicity of the latter was higher for young mice, amounting to $117.5 \%$ as compared to its toxicity for adult animals. This result for bemegride alone was not confirmed in our present experiments. After premedication, however, the toxicity of bemegride was significantly higher for young mice, this difference being the only one that reached statistical significance in the present study.

The doses of the two central analeptics were chosen according to the results of our previous experiments ( $\zeta_{i m}$ unek et al. 1968) where the $L_{50}$ values for bemegride and pentetrazole upon subcutaneous administration to mice were 41.5 and $102.0 \mathrm{mg} / \mathrm{kg}$ body mass, respectively. The $\mathrm{LD}_{50}$ of phenobarbital after subcutaneous administration was found by us in another study ( $\mathrm{Si}$ mun ek et al. 1971b) to be $218 \mathrm{mg} / \mathrm{kg}$ body mass for young mice and $257 \mathrm{mg} / \mathrm{kg}$ body mass for adult animals.

Considering that our previous experiments with drugs acting on the CNS and with sulphadimidine ( $\zeta$ i mu nek 1974) revealed no changes in the toxicity of phenobarbital, our present tests with phenobarbital included determination of its $\mathrm{LD}_{50}$ after sulphadimidine premedication, whereas those with the analeptics were confined to evaluation of the changes in the occurrence of convulsions and subsequent mortality. The effect of sulphadimidine premedication on acute toxicity of phenobarbital was manifested by an increase in its toxicity, particularly in the younger group where even phenobarbital alone was more toxic than in adult mice. No direct explanation of the mechanism underlying the interaction emerges from our experiments. One possibility to be considered is competition for the binding sites of proteins as suggested in studies on similar drugs by Csögör et al. (1971) and Csögör and Papp (1969). Determination of sulphonamide levels in our previous experiments ( changes upon interaction with phenobarbital (the same being true also for bemegride and pentetrazole) but it should be pointed out that the technique used in the study, a modification of the Bratton-Marshall method by Wagner (1950), makes no distinction between the quantities of free (directly reacting) and protein-bound sulphonamide so that changes in the binding to proteins, if present, cannot be determined in this way. The age-dependent difference in sulphonamide blood levels reported by us previously ( i imůnek 1974) made itself felt even upon interaction. Berecký and Lopuchovský (1979), in a study on adult white mice, found a decrease in sulphonamide concentration of some tissues only after as many as three phenobarbital treatments given during 24 hours, an observation ascribed by them - in keeping with relevant literature - to enhanced biotransformation of sulphonamide after enzyme induction by phenobarbital.

The manifestations of interactions of the two central analeptics with sulphadimidine in the present study were particularly marked in the younger mice, without being much affected by sulphadimidine dose. An increase in the toxicity of the two analeptics after sulphonamide premedication was also found in our previous exploratory experiments ( $\mathrm{S}$ i můn ek 1974). As regards pentetrazole, our present results are in reasonable agreement with the data reported by Horáková et al. (1963) for sulphadimethoxin. No direct data on the mechanism of such action have been published. However, a certain role in the interaction of sulphadimidine with central analeptics can presumably be ascribed to their sulphonamide-retarded metabolism in the liver as was pointed out, for example, by Skovsted et al. (1974). 


\section{Ovlivnění toxicity fenobarbitalu, pentetrazolu a bemegridu sulfadimidinem} u rozdílně starých myší

U bílých myši konvenčního chovu o hmotnosti $12-16$, resp. $22-27 \mathrm{~g}$ byla stanovena akutní subkutánní toxicita sodné soli fenobarbitalu, injekčního roztoku bemegridu a pentetrazolu, a to jak těchto farmak samotných, tak po premedikaci sodnou solí sulfadimidinu $\mathrm{v}$ dávce $0,2 \mathrm{~g} / \mathrm{kg}$ ž. h. Toxicita fenobarbitalu samotného byla vyšší pro myši mladší; toxicita obou analeptik CNS pro mladší myši byla nižší než pro starší. Po premedikaci sulfadimidinem se zvýšila toxicita všech zkoušených farmak, a to zvláště u mladší věkové skupiny myši.

\section{Влияние на токсичность фенобарбитала, пентетразола и бемегрида сульфадимидином у мышей разного возраста}

У белых мышей классического разведения массой 12-16 или 22-27 т проводились определения острой подкожной токсичности натриевой соли фенобарбитала, инъекционного раствора бемегрида и пенетразола, собственных фармакологических препаратов и после премедикации натриевой солью сульфадимидина дозой 0,2 г/кг живого веса. Токсичность собственного фенобарбитала была выше у мышей младшего возраста, токсичность обоих анапептиков CHS для молодых мышей была ниже чеи у старших. После премедикации сульфадимидином токсичность у всех проверяемых фармакологических препаратов увеличилась, в особенности у младшей возрастной группы мышей.

\section{References}

BENTZ, H. (Hrsg.): Veterinärmedizinische Pharmakologie. VEB Gustav Fischer Verlag Jena $1982,676 \mathrm{p}$.

BERECKÝ, I. - LOPUCHOVSKÝ, J.: Ovplyvnenie farmakokinetiky sulfadimidinu niektorými látkami. Biol. - chem. - Vet., 15, 1979: 341 - 351.

CSÖGÖR, S. I. - PÁLFFY, B. - FESZT, G. - PAPP, J.: Influence du sulfathiazol sur l'effet narcotique du Thiopental et de L'Hexobarbital. Rev. Roum. Physiol., 8, 1971: 81-85.

CSÖGÖR, S. I. - PAPP, J.: Competition between sulfonamides and barbiturates for the binding sites of plasma proteins. Abstr. $4^{\text {th }}$ Int. Congr. Pharmacol. Basel 1969: 494.

DUNAJEV, V. V. - PETROV, V. K. - TARBAJEVA, E. P. - ČERNOV, J. P.: Vlijanie fenobarbitala, etanala $i$ ich posledovate Inych naznačenii na funkcionalnuju sposobnost' tkani pečeni. Farmakol. i toksikol., 43, 1980: 319-324.

HORÁKOVÁ, Z. - MURATOVÁ, J. - PUJMAN, V. - BYDŽOVSKÝ, V.: Sulfonamidy s předpokládanou antibakteriální účinností. Farmakologie sulfamethoxydinu. Ceskoslov. farm., 12, 1963: 73-77.

KRISHNA, G. - BONANOMI, L.: Covalent binding of chloramphenicol as a biochemical basis for chloramphenicol - induced bone marrow damage. Drug Interactions, Raven Press New York 1974, p. 406: 173-180.

KVĚTINA, J. - FENDRICH, Z.: Farmakologické interakce. Pokroky ve farmacii 1. Avicenum Praha 1978: $11-108$.

LEE, S. W. - FOLEY, E. J.: A general theory for the mode of action of the sulfonamides. J. amer. Pharmac. Assoc., 33, 1944: 82-84.

LITCHFIELD, J. T. Jun. - WILCOXON, F. W.: A simplified method for evaluating dose-effect experiments. J. Pharm. exptl. Ther., 96, 1949: 99-113.

MITCHÉL, R. G.: The sulfonamides in childhood. Practitioner, 204, 1970: 20-26.

MYSLIVEC, V.: Statistické metody zemědělského a lesnického výzkumnictví. CSAZV-SZN Praha 1957: p. 555.

SATO, J. - UEDA, :. - SAITO, A. - TADA, H. - OWADA, E. - ITO, K. - MURATAT.: Effect of acetazolamide on barbiturate - induced sleeping time in mice. III. Pharmacokinetics of serum elimination and brain distribution. J. Pharm. Dyn. 6, 1983: 381-390. 
SKOVSTED, L. - HANSEN, J. M. - KRISTENSEN, M. - CHRISTENSEN, L. K.: Inhibition of drug metabolism in man. Drug Interactions, Raven Press. New York 1974, p. 406: $81-90$.

STONE, W. E. - JAVID, M. J.: Quantitative evaluation of the actions of anticonvulsants against different chemical convulsants. Arch. int. Pharmacodyn. Thérap., 240, 1979: 66-78.

SIMƯNEK, J.: Problematika dosologie léčiv v souvislosti s ontogenetickými změnami u zviřat zejména se zřetelem k sulfonamidům. DrSc. thesis. VŠV Brno 1974, 239 p.

SIMƯNEK, J.: Effect of sulphamethazine of the antipentetrazole action of diazepam in cockerels of different ages. Vet. Res. Commun. 7, 1983: 203-204.

ŠIMU゚NEK, J. - HEGEROVÁ, E. - KLIMEŚOVA, J. - ZAVADILOVÁ, R.: Effect of sulphadimidine on the toxicity of phenobarbital in cockerels of different ages. Acta vet. Brno 54, 1985: $183-187$.

S̆IMƯNEK, J. - KOVAR̆IK, O. - KYSELÝ, K.: Toxicita bemegridu a pentetrazolu pro mladé a dospělé bílé myši. Veterinaria Spofa, 13, 1971a: 133-142.

SIMƯNEK, J. - KUDRNA, K. - KYSELÝ, K. - KOVARÍK, O.: Toxicity of phenobarbital and its influence on the spontaneous activity of young and adult mice. Acta vet. Brno, 40, 1971b: $307-314$.

ŠIMƯNEK, J. - NEUMANN, J. - PLÍŠEK, K. - MAŠKOVA, J. - ŽALUD, K.: Porovnání některých farmakologických účinků bemegridu a pentetrazolu (Akutní toxicita, antinarkotický účinek a vliv na dýchání). Veterinaria Spofa, 10, 1968-65-80.

WAGNER, J.: Mikrostanovení sulfonamidů pro klinické účely. Cas. Lék. čes., 89, 1950: 262-264. 